\title{
Purinergic and Muscarinic Modulation of the Cell Cycle and Calcium Signaling in the Chick Retinal Ventricular Zone
}

\author{
Rachel Pearson, ${ }^{1}$ Marina Catsicas, ${ }^{1}$ David Becker, ${ }^{2}$ and Peter Mobbs ${ }^{1}$ \\ Departments of ${ }^{1}$ Physiology and ${ }^{2}$ Anatomy, University College London, London WC1E 6BT, United Kingdom
}

\begin{abstract}
Spontaneous calcium transients occur in the ventricular zone of the chick retina and result from the endogenous release of neurotransmitters in the absence of action potentials. Calcium transients resulting from the activation of purinergic and muscarinic receptors occur in a mixed population of interphase and mitotic cells, whereas those produced by ionotropic GABA and glutamate receptors are mostly restricted to the interphase population, the GABA responses primarily coming from cells
\end{abstract}

that express the neuronal marker TuJ-1. Muscarinic and purinergic receptors can act respectively as a brake and an accelerator on mitosis, whereas GABA and glutamate receptors are without effect. Our results suggest that the balance between muscarinic and purinergic activation acts to control the rate of retinal proliferation in early development.

Key words: glutamate; GABA; mitosis; chick embryo; eye; calcium signaling
The vertebrate eye originates from the optic vesicle, an evagination of the neural tube, which in turn invaginates to form a two-layered structure, the optic cup. The inner layer develops to produce the neurons and radial glia of the neural retina, whereas the outer monolayer of epithelial cells forms the retinal pigment epithelium (RPE). Within the neural retina, mitosis is confined to the layer of progenitor cells immediately adjacent to the RPE, the ventricular zone (VZ); the nuclei of retinal progenitor cells undergo interkinetic nuclear migration, moving from the $\mathrm{VZ}$ to the prospective ganglion cell layer (GCL) in $G_{1}$ of the cell cycle, before duplicating their DNA in S phase, and returning to the VZ in $G_{2}$ and undergoing mitosis (Fig. 1) (for review, see Jacobson, 1978). The chick retina consists of $\sim 200$ million cells; nearly all of these are produced within the $10 \mathrm{~d}$ period after the formation of the optic cup. This corresponds to the production of $\sim 250$ cells/ sec. These must be produced in the correct numbers, adopt the correct fate, migrate to their final destination, and form synaptic connections with the appropriate partners. To ensure the proper function of the adult retina, these processes must be highly regulated.

The production of cells by CNS progenitors and the determination of their fate are known to be regulated via an array of diffusible factors such as fibroblast growth factors (FGFs), which are thought to play key roles in the initial development of retinal ganglion cells from the undifferentiated neuroepithelium (McCabe et al., 1999). Contact-mediated interactions, such as those involving the transmembrane proteins notch and delta, play a critical role in the generation of neuronal diversity in the vertebrate retina (for review, see Perron and Harris, 2000). In addition, there is growing evidence for the involvement of a variety of both slow and fast neurotransmitters in the regulation of cell proliferation. Acetylcholine, acting via muscarinic receptors, can

Received Feb. 26, 2002; revised May 23, 2002; accepted May 28, 2002.

This work was supported by the Medical Research Council, the Wellcome Trust, and the Biotechnology and Biological Sciences Research Council. We thank David Attwell and Jonathon Clarke for comments on this manuscript.

Correspondence should be addressed to Peter Mobbs, Department of Physiology, University College London, Gower Street, London WC1E 6BT, UK. E-mail: P.Mobbs@ucl.ac.uk.

Copyright (C) 2002 Society for Neuroscience $\quad 0270-6474 / 02 / 227569-11 \$ 15.00 / 0$ stimulate cortical precursors cell proliferation or, under different experimental conditions, inhibit DNA synthesis (Baumgold and Dyer, 1994; Nicke et al., 1999; Ma et al., 2000; Li et al., 2001). In eye development, muscarinic receptors may be involved in the control of eye length (Tigges et al., 1999; Schwahn et al., 2000). Purine nucleotides and nucleosides can increase or decrease DNA synthesis in glia and neurons (Ciccarelli et al., 1994; Sugioka et al., 1999a,b). GABA has also been reported to be able to both increase (Fiszman et al., 1999; Haydar et al., 2000) and decrease (LoTurco et al., 1995) cell proliferation and to partially block the mitogenic actions of basic FGF in the cortex (Antonopoulos et al., 1997). Like GABA, glutamate may also increase or decrease cell proliferation in the cortex by changing the cell cycle time; both glutamate and GABA increase the size of cortical VZ clones but decrease subventricular zone clone size (Haydar et al., 2000). In the cortex, LoTurco et al. (1995) have shown that, applied alone, $\mathrm{GABA}_{\mathrm{A}}$ and AMPA/kainate receptor antagonists increase proliferation by increasing DNA synthesis, whereas applied together, they decrease it.

The intracellular calcium concentration $\left(\left[\mathrm{Ca}^{2+}\right]_{\mathrm{i}}\right)$ has a key influence on developmental events in the CNS and has been implicated in the regulation of differentiation, migration, cell fate, and circuit formation. In the VZ of the neocortex, individual cells display intermittent spontaneous calcium transients (Owens and Kriegstein, 1998). These transients do not depend on the activation of voltage-sensitive sodium channels, voltage-operated calcium channels (VOCCs), or amino acid neurotransmitter receptors. Here we have used confocal microscopy and a combination of the vital chromatin dye Hoechst 33342 and the calcium indicator Fluo-4 to relate spontaneous changes in $\left[\mathrm{Ca}^{2+}\right]_{i}$, as well as those evoked by muscarinic, purinergic, glutamatergic, and GABAergic stimulation, to the mitotic status of the cells in the $\mathrm{VZ}$ and to look at the role of these receptors in regulating the cell cycle in the embryonic chick retina.

\section{MATERIALS AND METHODS}

White Leghorn chicken eggs were incubated at $37^{\circ} \mathrm{C}$. Embryos at embryonic day 4 (E4) or E6 were killed by decapitation, and their eyes were removed. 
Calcium imaging. Retinas were dissected from the eye cup at room temperature in Krebs' solution containing (in $\mathrm{mm}$ ): $100 \mathrm{NaCl}, 30$ $\mathrm{NaHCO}_{3}, 6 \mathrm{KCl}, 3 \mathrm{NaH}_{2} \mathrm{PO}_{4}, 1 \mathrm{MgCl}_{2}, 1 \mathrm{CaCl}_{2}$, and 20 glucose, $\mathrm{pH} 7.4$, by gassing with $5 \% \mathrm{CO}_{2}$ and $95 \% \mathrm{O}_{2}$. To monitor spontaneous and induced calcium activity, retinas were loaded by immersion in Krebs' solution containing Fluo-4 AM (10 $\mu \mathrm{M}$; Molecular Probes, Eugene, OR) and the dispersant Cremophor-EL (0.03\%; Sigma, St. Louis, MO) for 1 $\mathrm{hr}$ at room temperature (for exogenous agonist applications) or at $37^{\circ} \mathrm{C}$ (for spontaneous activity). Ten minutes before the end of Fluo-4 loading, the vital chromatin dye Hoechst 33342 ( $2 \mu \mathrm{M}$; Molecular Probes) was added to the loading medium. After loading, the retinas were maintained in gassed solution at room temperature or $37^{\circ} \mathrm{C}$ (as above). Retinas were transferred to a perfusion chamber on the stage of an inverted microscope and held flat with nylon strands glued to a platinum frame. The tissue was continually superfused with Krebs' solution delivered via a peristaltic pump and imaged at either room temperature or $37^{\circ} \mathrm{C}$ (as above). When imaging activity, pairs of retinas from one embryo were always used, with one as a control and the other for drug application, alternating the order of their use between experiments. High-K ${ }^{+}(20$ $\mathrm{mM}$ ) Krebs' solution produced increased fluorescence in virtually all cells in all retinas challenged, indicating that there was effective loading of cells with the $\mathrm{Ca}^{2+}$ indicator dye.

Image acquisition, storage, and analysis. Retinas were imaged as flat mounts, with the VZ facing the objective, using an inverted confocal microscope (LSM510; Zeiss). The fluorescence of Fluo-4 and Hoechst 33342 was excited with the $488 \mathrm{~nm}$ line of the argon laser and the $350 \mathrm{~nm}$ line of the UV laser, respectively. In $\mathrm{Ca}^{2+}$ imaging experiments, single Hoechst images were taken before and after drug application. Fluo-4 images were acquired at 4 sec intervals and analyzed off-line using Lucida software (Kinetic Imaging Ltd.). Cells were selected at random from the Hoechst images to prevent subjective selection. The mean fluorescence of individual cells chosen at random was calculated and normalized to its initial value at time 0 . Increases in the fluorescence of Fluo-4 reflect increases in $\left[\mathrm{Ca}^{2+}\right]_{\mathrm{i}}$. For studies of the effects of drugs on mitosis, tissue was labeled with Hoechst 33342 as described above, and images were taken at $15 \mathrm{sec}$ intervals for up to $90 \mathrm{~min}$. All images were 12 bit and subject to $\mathrm{x} 2$ line averaging. Figures always show single confocal sections through the VZ.

Drugs and statistical analysis. In imaging experiments, the following drugs were applied by bath perfusion: carbachol, pirenzipine, UTP, suramin, GABA, bicuculline, glutamate (all from Sigma), AMPA, and NBQX (both from Tocris). Traces show the application of drugs, as indicated, to single retinas. A change in fluorescence in excess of a criterion level of $10 \%$ above baseline was considered a response.

All of the quantitative data presented were tested using Student's $t$ test, and differences were considered statistically significant at one of two levels: ${ }^{*} p<0.05$; and ${ }^{*} p<0.01$. The results are means $\pm \mathrm{SEM}$, where $N$ is the number of retinas investigated, and $n$ is the number of cells recorded.

Application of drugs in ovo. Eggs were "windowed" at E5, and the inner membranes were opened. Agonists (final concentration in the egg, 50 $\mu \mathrm{M}$ ) and antagonists (final concentration, $25 \mu \mathrm{M}$ ) were injected into the amniotic pouch, using a micropipette, close to the heart of the embryo. Controls received sham injections of PBS. Eggs were resealed and incubated for $6 \mathrm{hr}$ at $37^{\circ} \mathrm{C}$. The embryos were fixed in ovo with paraformaldehyde (PFA; TAAB Laboratories Equipment Ltd.; 4\% in PBS) and maintained in vitro in PFA for a further $6 \mathrm{hr}$ at $4^{\circ} \mathrm{C}$. After three rinses with PBS, the embryos were placed in $20 \%$ sucrose and PBS overnight at $4^{\circ} \mathrm{C}$. Eye diameter was measured through the choroid fissure. Data from controls were pooled, and the mean diameter was calculated. The mean diameters of eyes treated with drugs are expressed as a fraction of that of the controls.

For sectioning, the eyes were embedded in Tissue-Tek OCT (Sakura Finetek Europe BV) and frozen. Transverse sections $20 \mu \mathrm{m}$ thick were prepared in a cryostat (2800 Frigocut-E; Leica) and affixed to poly-Llysine-coated slides. Sections passing through the center of the retina, adjacent to the optic nerve, were processed as follows: Hoechst 33342 (2 $\mu \mathrm{M})$ in PBS was applied to sections for $5 \mathrm{~min}$ in the dark, and then the sections were washed for a further $5 \mathrm{~min}$ in PBS before mounting in Citifluor (Citifluor Ltd.). Hoechst fluorescence was detected using an inverted confocal microscope as described above. Ten areas within each section were selected at random and imaged. This procedure was repeated on three sections from the eye of each embryo, and the number of mitotic cells $/ 100 \mu \mathrm{m}$ length of retina was calculated. The final results are shown as the percentage difference compared with controls.
Immunocytochemistry. Retinas from E6 chicks were loaded with Fluo-4 and Hoechst, and changes in chromatin and $\left[\mathrm{Ca}^{2+}\right]_{\mathrm{i}}$ were imaged during drug application (see above). The retinas were left in place on the stage of the microscope and fixed by immersion in $4 \%$ PFA and PBS for $2 \mathrm{hr}$ at room temperature. After three $30 \mathrm{~min}$ rinses in PBS, tissue was permeabilized for $12 \mathrm{hr}$ using $1 \%$ Triton X-100 in $0.1 \mathrm{M} \mathrm{L}-$ lysine and PBS (blocking solution). Blocking solution containing a monoclonal mouse anti-TuJ-1 primary antibody (1:500; Cambridge Biotech) was then applied for $18 \mathrm{hr}$. After rinsing in PBS, retinas were incubated in antimouse Cy5-tagged secondary antibody (1:200; Cambridge Biotech) for $24 \mathrm{hr}$. After rinsing off the excess secondary antibody with PBS solution containing $2 \mu \mathrm{M}$ Hoechst, the retinas were reimaged on the confocal microscope. The exact same region as that monitored during $\mathrm{Ca}^{2+}$ imaging was reidentified using the Hoechst profiles before the fluorescence of Cy5 was excited with the $633 \mathrm{~nm}$ line of the HeNe laser. Because the chick retina lacks conspicuous landmarks, processing of the retina on the stage of the microscope without moving the preparation was found to be absolutely necessary to be able to come back to the region visualized during $\mathrm{Ca}^{2+}$ imaging. The difficulty of this experiment meant we were only able to perform it satisfactorily once, after application of GABA. Negative controls consisted of retinas processed as above but in the absence of primary antibody. The procedures were all conducted at room temperature.

\section{RESULTS}

\section{Interphase and mitotic cell populations in the VZ}

Incubation of E6 chick retina in Fluo-4 AM leads to labeling of the majority of the cells in the VZ. Two populations can be identified on the basis of cell diameter and the intensity of Fluo-4 labeling at resting $\mathrm{Ca}^{2+}$ levels. One consists of large, dark profiles $(4.6 \pm 0.2 \mu \mathrm{m} ; n=80)$, and the other consists of smaller $(2.7 \pm$ $0.2 \mu \mathrm{m} ; n=80$ ), more brightly labeled cells (Fig. $1 D$ ). Comparison of Fluo-4 labeling with that of the same retina by Hoechst 33342 shows that the majority of the large, dark cells contain mitotic figures, whereas the chromatin of the more brightly labeled somata is typical of that of interphase nuclei (Fig. 1E). Labeling with TuJ-1 (Fig. 1F), an antibody for neuron-specific tubulin and a marker of postmitotic neurons (Lee et al., 1990), shows that approximately one-third of the interphase cells of the $\mathrm{VZ}(36 \pm 3 \% ; N=3 ; n=212)$ are TuJ-1-positive, whereas $<2 \pm$ $1 \%(N=3 ; n=85)$ of cells containing mitotic figures stain for TuJ-1. Thus, at E6 the VZ layer consists of mitotic cells, which are large, label dimly with Fluo-4 AM, and are seldom TuJ-1positive, and a brightly labeling interphase population that contains a mixture of progenitor cells (TuJ-1-negative and making up approximately two-thirds of the total interphase population) and differentiating neurons (TuJ-1-positive). Although we did not attempt to label glial cells, Müller cells are likely to be present only in small numbers, because the majority are born much later (Prada et al., 1991).

\section{Spontaneous $\left[\mathrm{Ca}^{2+}\right]_{i}$ fluctuations in the VZ}

To examine the possibility that retinal VZ cells produce spontaneous $\left[\mathrm{Ca}^{2+}\right]_{\mathrm{i}}$ fluctuations, we imaged $\mathrm{E} 6$ retinas superfused with Krebs' solution at $37^{\circ} \mathrm{C}$ (Fig. 2). Many cells exhibited spontaneous $\left[\mathrm{Ca}^{2+}\right]_{\mathrm{i}}$ transients (Fig. $2 A$ ). Such spontaneous activity was rare at room temperature. Most transients occurred at low frequency (approximately one event per cell every $4 \mathrm{~min}$ ) and usually did not propagate into neighboring cells (but see below). The events had a mean duration at half-peak of $13.8 \pm 1.3 \mathrm{sec}$ and occurred with approximately equal frequency in both mitotic and interphase cells. The application of TTX $(10 \mu \mathrm{M})$ failed to reduce the frequency of spontaneous activity ( $p=0.42$ ) (Fig. $2 B$ ); thus these events seem to be independent of action potential production. Occasionally, simultaneous spontaneous events occurred in neighboring cells. Sometimes these paired events represented the 

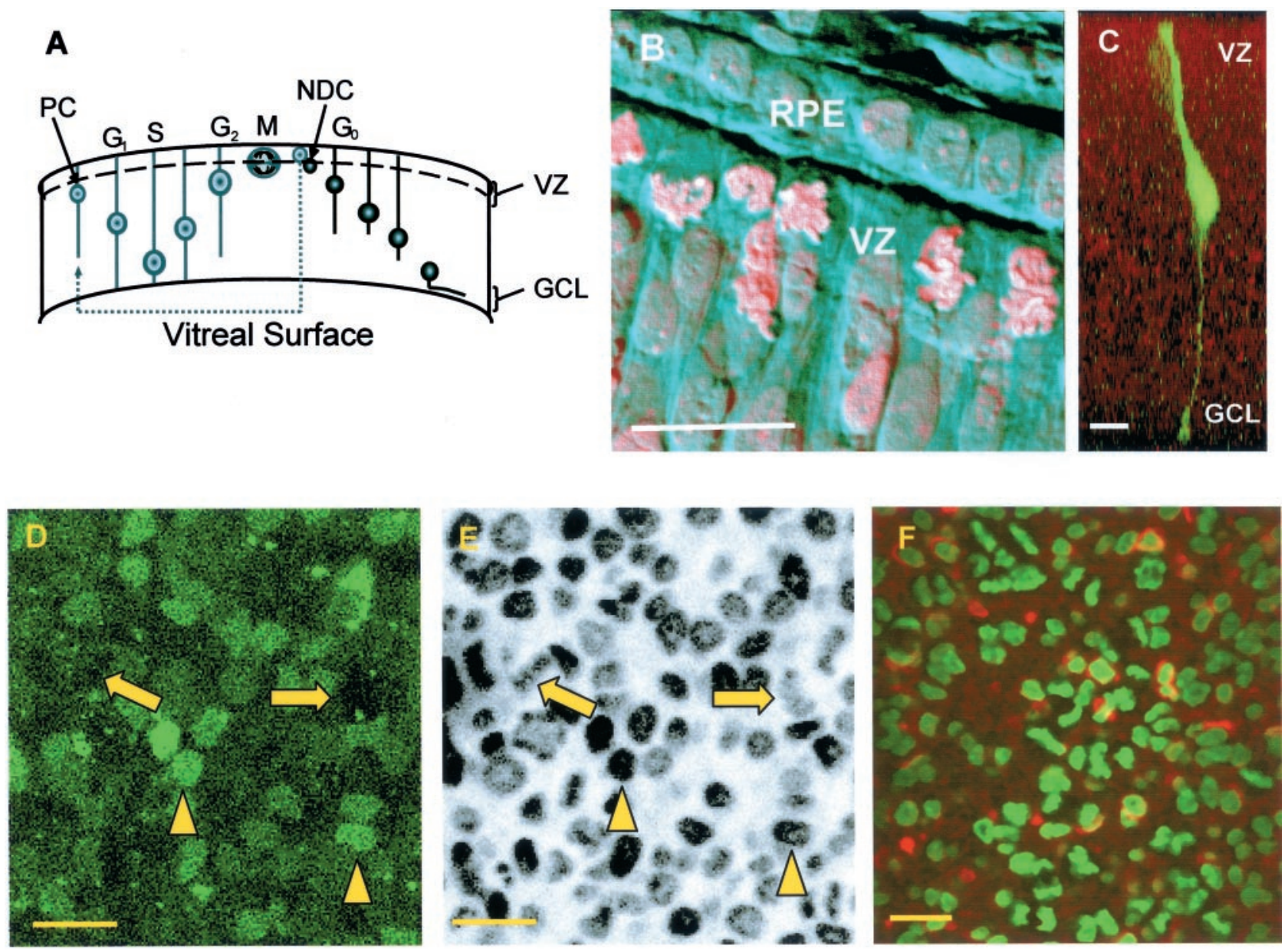

Figure 1. The cell cycle in the chick retina. $A$, Progenitor cells $(P C)$ undergo interkinetic nuclear migration. In this process, the nucleus moves between the VZ, which is permissive for mitosis $(M)$, and the GCL. The nucleus moves toward the GCL in $\mathrm{G}_{1}$, replicates its DNA (S phase), and returns toward the $\mathrm{VZ}$ in $\mathrm{G}_{2}$. Throughout this period, the cell retains contact with both surfaces of the retina by means of thin cytoplasmic processes. During the transition from $\mathrm{G}_{2}$ to $\mathrm{M}$ phase, the cell retracts its vitreal process before dividing. PCs can either undergo symmetrical division, in which both daughter cells continue in the cell cycle, or divide asymmetrically to give rise to a PC and a newly differentiated cell (NDC) that then migrates to its final location. $B$, Combined phase contrast and fluorescence image of a section through an E6 chick retina, stained with propidium iodide. Mitotic cells are confined to the VZ and contact the RPE. Mitotic cells can be identified by the presence of strongly staining and highly condensed chromatin that contrasts with the weakly stained and dispersed chromatin of the interphase cells. $C$, Single PC injected with FITC and dextran to show the processes that extend to the ventricular and vitreal surfaces. The nucleus of the cell is located in the bulge within the cell below the VZ. D, E, VZ cells can be labeled with both Fluo-4 AM, to measure their $\left[\mathrm{Ca}^{2+}\right]_{\mathrm{i}}$ responses, and Hoechst 33342, to determine their mitotic status. $D$, In Fluo-4-labeled preparations, two distinct populations of cells can be identified within the VZ. Large, dark cells (arrows) with an average diameter of $4.6 \pm 0.2 \mu \mathrm{m}(n=80 ; N=3)$ and smaller, more brightly labeled ones (arrowheads) of $2.7 \pm 0.2 \mu \mathrm{m}(n=80 ; N=3)$ in diameter. Cells were viewed at resting [Ca $\left.{ }^{2+}\right]_{\mathrm{i}} . E$, Same cells shown in A labeled with Hoechst $33342(2 \mu \mathrm{M})$. The large profiles contain condensed chromatin and are mitotic (arrows). The chromatin within the nuclei of the brightly labeled and smaller cells is typical of cells in interphase (arrowheads). F, VZ of an E6 retina labeled with TuJ-1 (red), an antibody for neuron-specific tubulin, and Hoechst 33342 ( green). Approximately one-third of the interphase cells of the VZ are TuJ-1 positive (see Results). Scale bars, $10 \mu \mathrm{m}$.

spread of the transients between cells before cytokinesis (Fig. $2 C$ ). However, we also observed a more extensive spread of the transients, these events invading clusters of as many as a dozen cells (Fig. $2 D$ ). These phenomena, similar to those seen in the cortex (Owens and Kriegstein, 1998; Owens et al., 2000), suggest that $\left[\mathrm{Ca}^{2+}\right]_{\mathrm{i}}$ transients in the $\mathrm{VZ}$ may pass between cells via gap junctions or through the release of a neurotransmitter or some other extracellular factor.

\section{Spontaneous activity results from endogenous release of neurotransmitter}

Purinergic (Sugioka et al., 1996), muscarinic (Sakaki et al., 1996), GABAergic (Yamashita and Fukuda, 1993), and glutamatergic (Sugioka et al., 1998) stimulations of the embryonic chick retina during neurogenesis have all been shown to cause increases in $\left[\mathrm{Ca}^{2+}\right]_{i}$, although the cells responding have not always been identified. We tested the possibility that the spontaneous $\left[\mathrm{Ca}^{2+}\right]_{\mathrm{i}}$ transients we observed in the $\mathrm{VZ}$ originated from endogenous activation of one or more neurotransmitter receptors within the E6 retina. We compared the frequency of the spontaneous events in retinas in the presence of the antagonists pirenzipine (to block muscarinic acetylcholine receptors), suramin (to block $\mathrm{P}_{2} \mathrm{Y}$ receptors), NBQX (to block AMPA receptors), and bicuculline (to block $\mathrm{GABA}_{\mathrm{A}}$ receptors) (all $25 \mu \mathrm{M}$ ) with those in controls. All four antagonists reduced the frequency of the $\left[\mathrm{Ca}^{2+}\right]_{\mathrm{i}}$ transients (Fig. 3). Pirenzipine and suramin (investigated at E4; see below) reduced the production of transients in both mitotic and inter- 

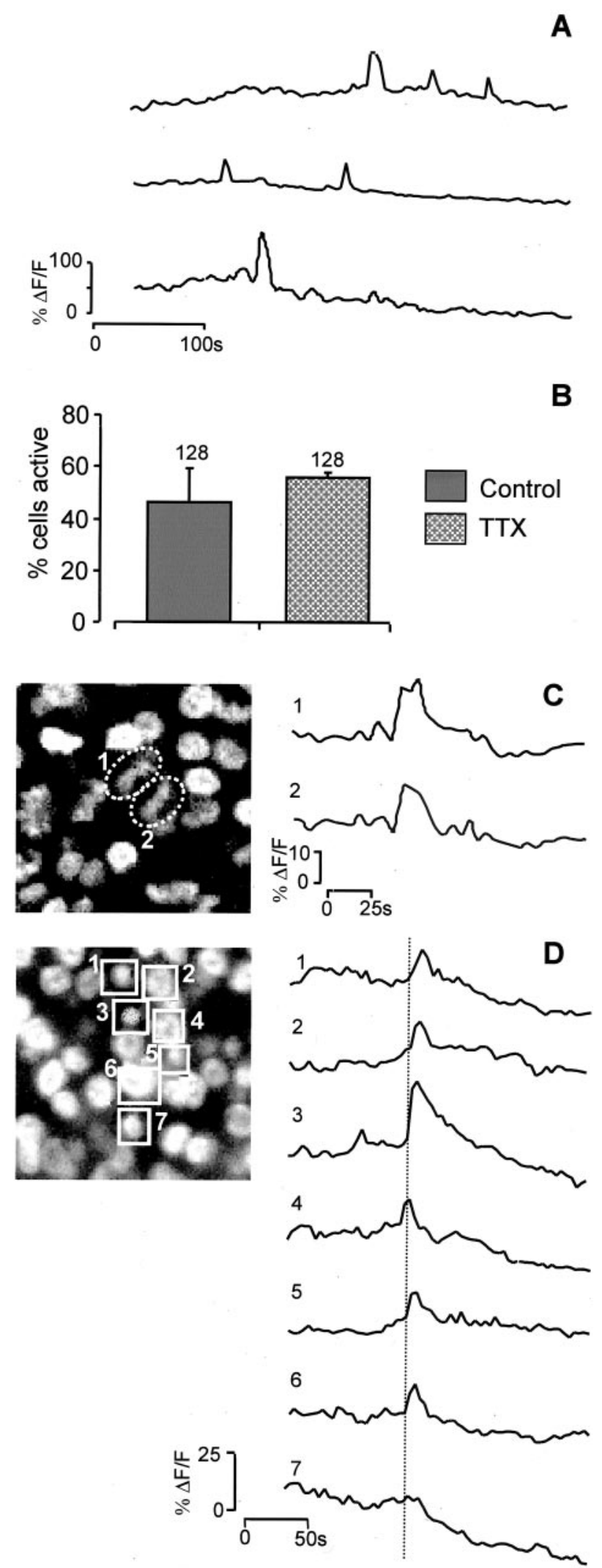

Figure 2. Spontaneous $\left[\mathrm{Ca}^{2+}\right]_{\mathrm{i}}$ transients in E6 VZ cells. $A$, Examples of the spontaneous changes in $\left[\mathrm{Ca}^{2+}\right]_{\mathrm{i}}(\Delta F / F)$ seen in individual cells in the $\mathrm{VZ}$ when the temperature is raised to $37^{\circ} \mathrm{C}$. In any given cell, events occurred approximately once every $250 \sec (n=99 ; N=3)$ and had durations of $13.8 \pm 1.3 \mathrm{sec}$. $B$, The frequency of spontaneous events is not reduced by the $\mathrm{Na}^{+}$channel blocker TTX $(10 \mu \mathrm{M} ; N=3)$. $C$, Paired event
Mitotic

$\square$ Interphase

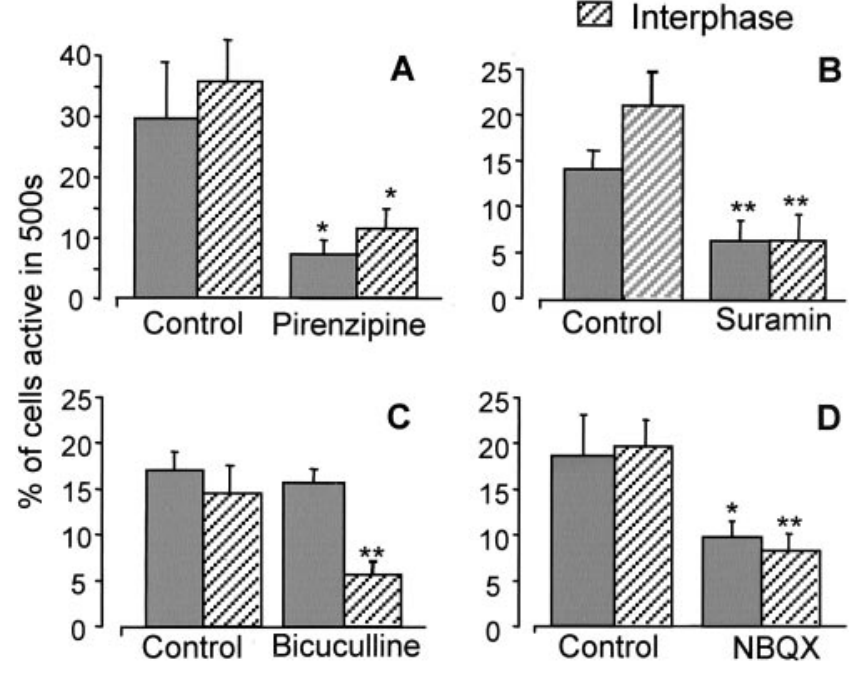

Figure 3. Spontaneous activity results from endogenous activation of neurotransmitter receptors. Graphs show the mean \pm SEM percent of a randomly selected sample of 500 cells demonstrating spontaneous activity within $500 \mathrm{sec}$ in control solution or in the presence of $25 \mu \mathrm{M}$ pirenzipine $(A)$, suramin $(B)$, bicuculline $(C)$, or NBQX $(D) .{ }^{*} p<0.05 ;{ }^{* *} p<0.01$ All retinas were E6, except with suramin (see Results), at which E4 retinas were used. $N=5 ; n=500$ in each condition.

phase cells similarly, by $68 \%(p<0.03)$ and $62 \%(p<0.01)$, respectively. At this time, NBQX had a similar but smaller effect, reducing transient production in both populations by $\sim 51 \%(p<$ $0.01)$. In contrast, bicuculline had no effect on $\left[\mathrm{Ca}^{2+}\right]_{i}$ transients in the mitotic population, whereas it reduced their occurrence in interphase cells by $68 \%(p<0.01)$.

\section{VZ cell populations respond to muscarinic, purinergic, glutamatergic, and GABAergic stimulation}

To determine the size and nature of the population of cells that respond to these neurotransmitter systems, we first applied specific agonists to E6 retina to stimulate purinergic and muscarinic receptors, respectively. UTP and carbachol (both $100 \mu \mathrm{M}$ ) produced marked increases in $\left[\mathrm{Ca}^{2+}\right]_{\mathrm{i}}$ in VZ cells (Fig. $4 A$, left $)$ that were suppressed by suramin and pirenzipine $(25 \mu \mathrm{M})$, respectively (Fig. $4 A$, right). Most cells $(94 \pm 2 \% ; N=10 ; n=671)$ responded to carbachol, and some responded to UTP $(11 \pm 5 \% ; N=6 ; n=$ 210). The responses to both of these agonists were often oscillatory. Nicotine $(100 \mu \mathrm{M})$ produced responses in $<6 \pm 2 \%(N=6$; $n=407)$ of cells, whereas muscarine $(100 \mu \mathrm{M})$ evoked $\left[\mathrm{Ca}^{2+}\right]_{\mathrm{i}}$ transients in $87 \pm 10 \%(N=4 ; n=265)$ (Fig. $4 B)$, showing that the muscarinic agonist carbachol, which acts with low potency at nicotinic receptors, produced its effects in most cells in the VZ via activation of muscarinic receptors. The responses to carbachol and UTP were unaffected by the $\mathrm{Ca}^{2+}$ channel blocker $\mathrm{Ni}^{2+}(100$ $\mu \mathrm{M} ; p=0.34)$, with $98 \pm 1 \%$ of cells producing criterion responses, but strongly suppressed by the presence of caffeine (10 $\mathrm{mm} ; p<0.01$ ), with only $3.5 \pm 2 \%$ of cells responding (Fig. $4 C, D$ ).

occurring between cells $(1,2)$ before cytokinesis. Left panel, Hoechst 33342 labeling showing the state of the chromatin in cells 1 and 2. D, Transients may spread to invade several cells. Seven interphase (1-7) cells are highlighted in the left panel (Hoechst 33342 labeling), and the change in $\left[\mathrm{Ca}^{2+}\right]_{\mathrm{i}}$ is plotted in the traces (right). The $\left[\mathrm{Ca}^{2+}\right]_{\mathrm{i}}$ transient observed is initiated in cell 4 and spreads to either side of it. 
A
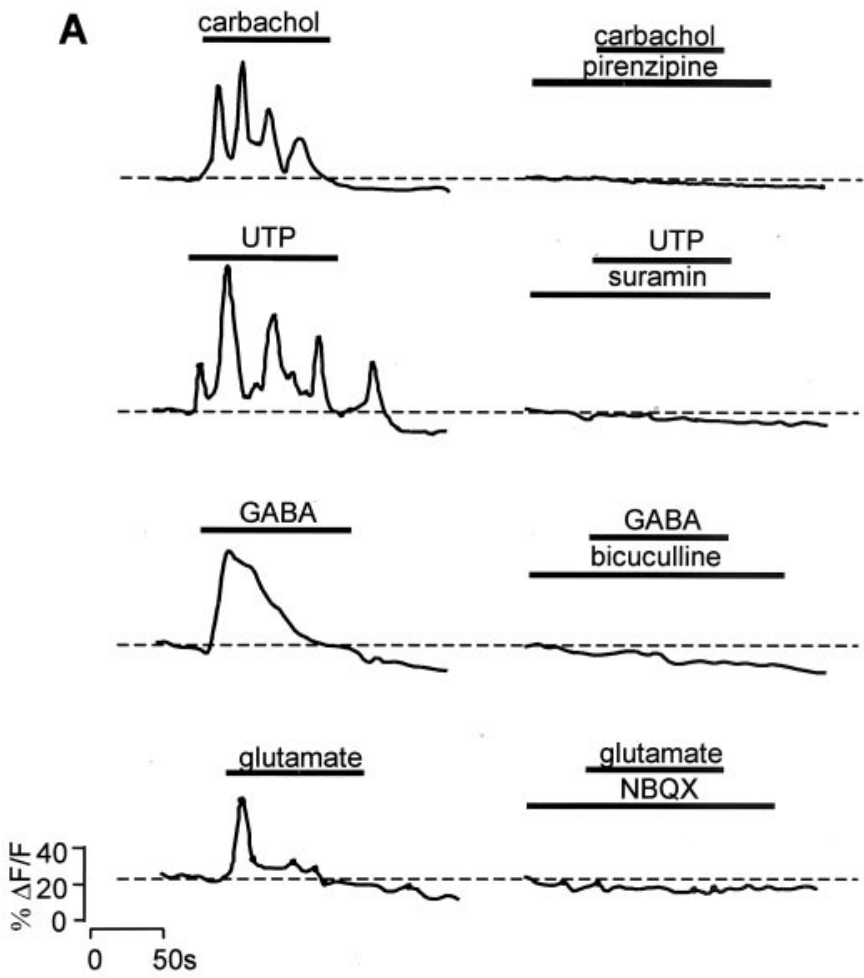

B

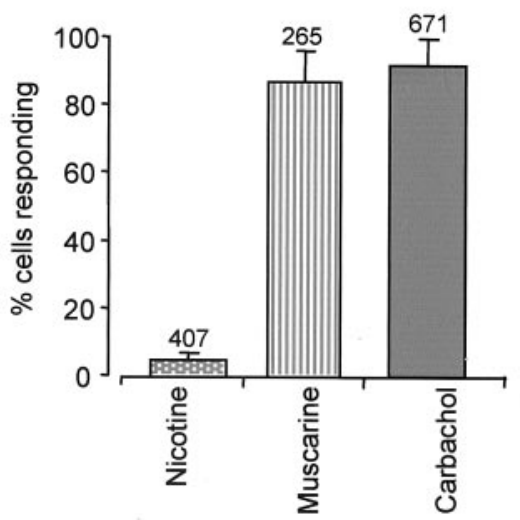

C
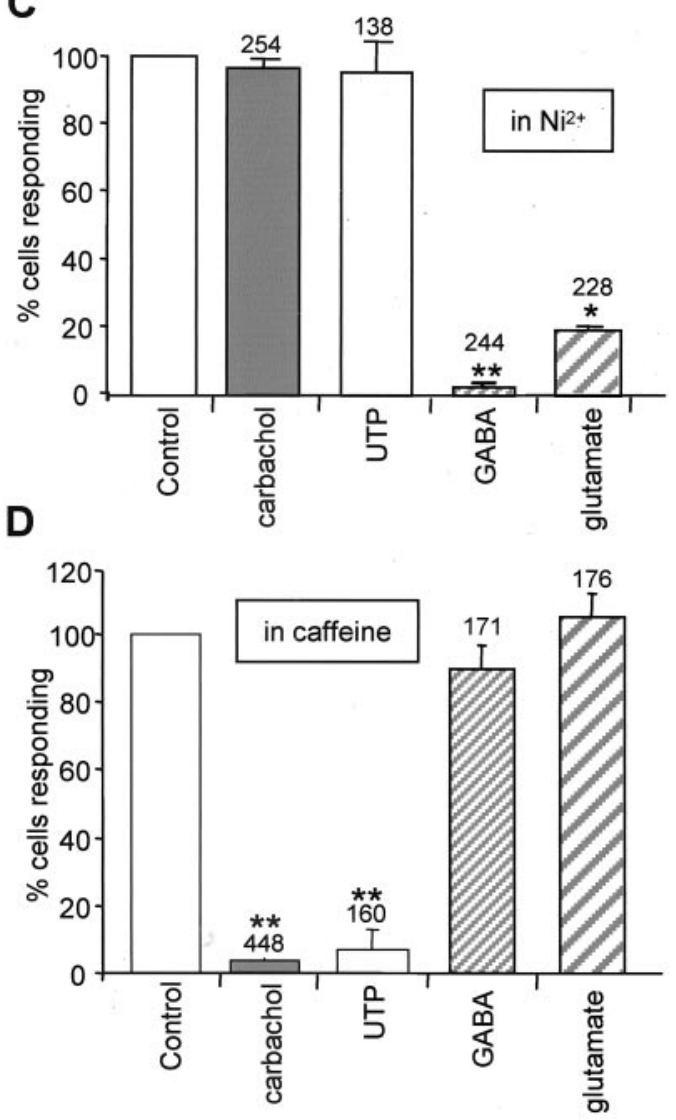

Figure 4. VZ cells in E6 retina respond to muscarinic, purinergic, glutamatergic, and GABAergic stimulation. $A$, Left, Exogenous application of carbachol, UTP, GABA, and glutamate (all $100 \mu \mathrm{M})$ produces increases in $\left[\mathrm{Ca}^{2+}\right]_{\mathrm{i}} ; 94 \pm 2 \%(n=671 ; N=10)$ of cells responded to carbachol; $11 \pm 5 \%(n=210 ; N=6)$ responded to UTP; $35 \pm$ $8 \%(n=240 ; N=6)$ responded to GABA; and $39 \pm 11 \%(n=280 ; N=6)$ responded to glutamate. The responses to GABA and glutamate were usually transient and declined monotonically with time, whereas those to UTP and carbachol were often oscillatory. A, Right, Responses to carbachol, UTP, GABA, and glutamate were suppressed by pirenzipine, suramin, bicuculline, and NBQX (all $25 \mu \mathrm{M}$ ), respectively. $B$, The response to carbachol is mediated by muscarinic receptors. Muscarine (100 $\mu \mathrm{M} ; N=4)$ produces responses in the same proportion of cells as carbachol (100 $\mu \mathrm{M}$; $N=7)$, whereas nicotine (100 $\mu \mathrm{M} ; N=6)$ stimulates only a small number. $C, D$, The $\left[\mathrm{Ca}^{2+}\right]_{\mathrm{i}}$ increase resulting from muscarinic and purinergic stimulation results from $\mathrm{Ca}^{2+}$ release from intracellular stores, whereas that from glutamatergic and GABAergic stimulation results from $\mathrm{Ca}^{2+}$ entry through VOCCs. $C, \mathrm{Ni}^{2+}(100 \mu \mathrm{M})$ greatly reduces the effects of GABAergic $(N=3)$ and glutamatergic $(N=3)$ stimulation but is without effect on responses to either UTP $(N=3)$ or carbachol $(N=$ $3)$. $D$, Ten millimolar caffeine greatly reduces the fraction of cells that respond to either muscarinic $(N=6)$ or purinergic $(N=3)$ stimulation but is without effect on responses to either GABA $(N=3)$ or glutamate $(N=3)$. Values plotted are the mean $\pm \mathrm{SEM} ;{ }^{* *} p<0.01$.

The results show that the $\left[\mathrm{Ca}^{2+}\right]_{\mathrm{i}}$ transients evoked by purinergic and muscarinic stimulation arise from the release of $\mathrm{Ca}^{2+}$ from intracellular stores rather than from the entry of $\left[\mathrm{Ca}^{2+}\right]_{0}$ via VOCCs.

Application of the fast transmitters GABA and glutamate (both $100 \mu \mathrm{M})$ also evoked $\left[\mathrm{Ca}^{2+}\right]_{\mathrm{i}}$ transients in VZ cells, both producing responses in approximately one-third of all VZ cells (35 \pm $8 \% ; N=6 ; n=240 ;$ and $39 \pm 11 \% ; N=6 ; n=280$, respectively) (Fig. $4 A$, left). In contrast to the responses produced via the activation of metabotropic receptors by carbachol or UTP, the increases in $\left[\mathrm{Ca}^{2+}\right]_{\mathrm{i}}$ evoked by GABA and glutamate consisted of single transients that declined monotonically with time. The GABA-evoked responses were suppressed by bicuculline, and those to glutamate were suppressed by NBQX (both $25 \mu \mathrm{M}$ ) (Fig.
$4 A$, right). Furthermore, the responses to GABA and glutamate were strongly suppressed by $\mathrm{Ni}^{2+}$; the numbers of cells responding were reduced to 1.5 and $20 \%$, respectively, of that seen in controls ( $p=0.01$ and 0.04 ) (Fig. 4C), whereas caffeine was without effect, with $89 \pm 7 \%(N=3 ; p=0.37)$ and $111 \pm 7 \%$ $(N=3 ; p=0.29)$ of cells producing criterion responses. This confirms that $\left[\mathrm{Ca}^{2+}\right]_{\mathrm{i}}$ transients produced by these two agonists resulted mainly from $\mathrm{Ca}^{2+}$ entry via VOCCs, as has been shown for whole chick retinas at times from E3 onward (Yamashita et al., 1993; Catsicas and Mobbs, 2001).

Using preparations colabeled with Hoechst 33342 and Fluo-4 AM, we examined the relationship between the mitotic status of cells in the VZ at E6 and their responses to neurotransmitters (Fig. 5A-C). Responses to carbachol and UTP arose equally from 

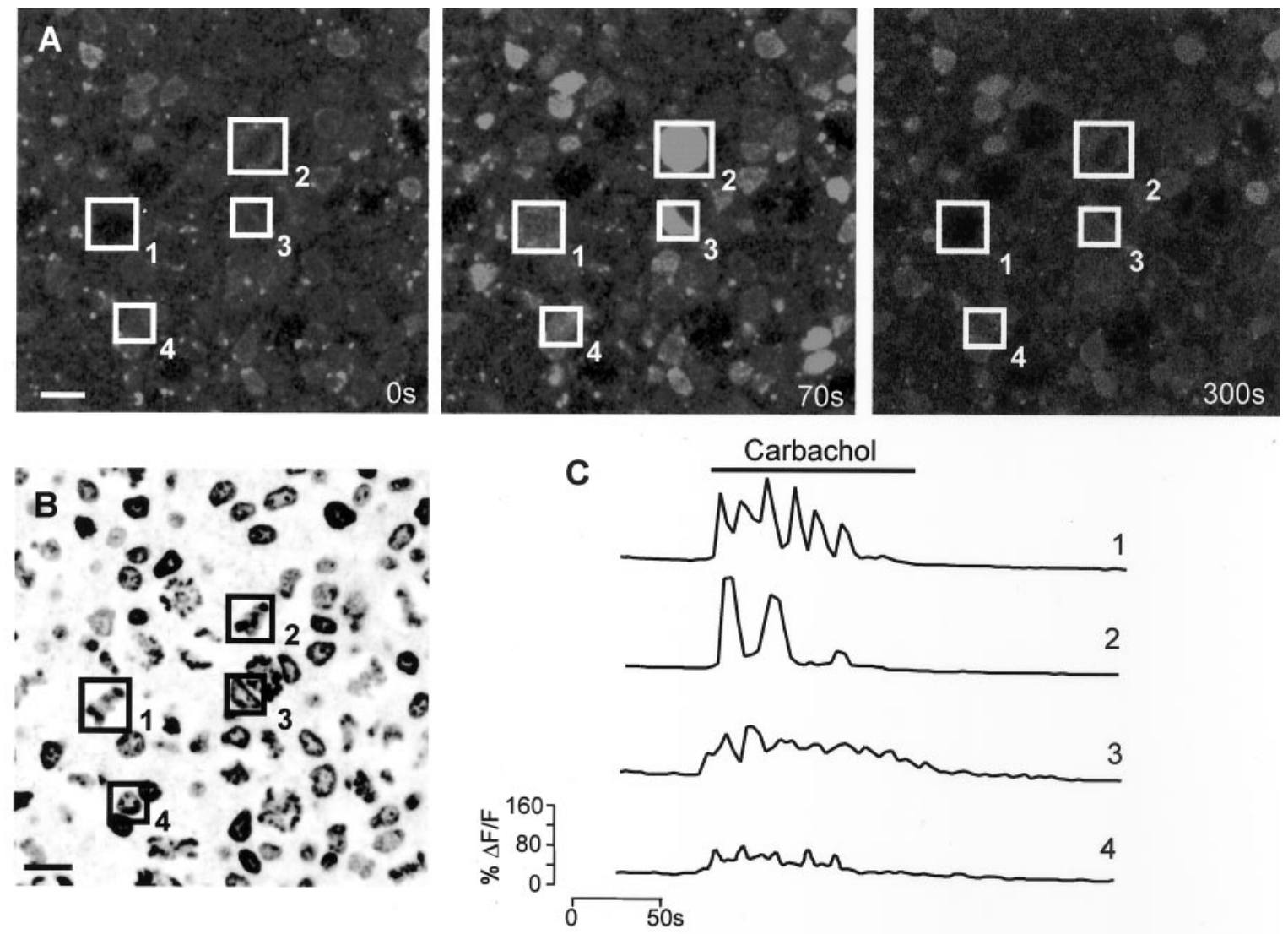

D

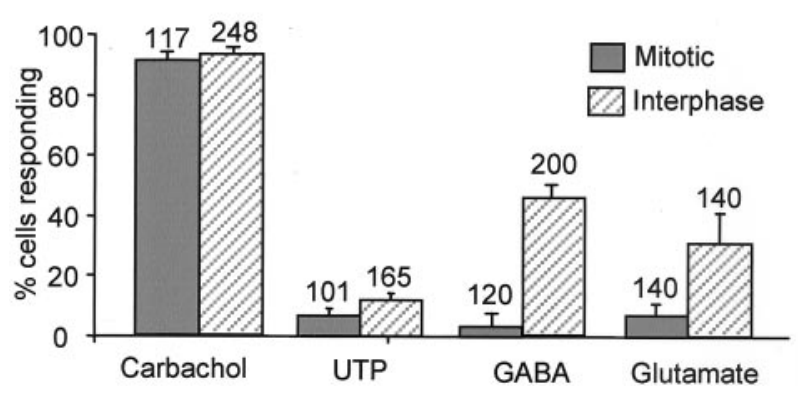

Figure 5. The mitotic and interphase $\mathrm{VZ}$ cell populations respond to different agonists. $A-C$, Changes in $\left[\mathrm{Ca}^{2+}\right]_{\mathrm{i}}$ can be correlated with the mitotic status of individual cells. $A$, Confocal image of flat-mount E6 retina labeled with Fluo-4 AM. Four cells are indicated by numbered boxes and show increased fluorescence in the presence of carbachol (center panel). Left, center, and right panels correspond to 0, 70, and 300 sec, respectively. $B$, Hoechst 33342 image of the same region shown in $A$ reveals that cells 1 and 2 are mitotic, and 3 and 4 are in interphase. Scale bar, $5 \mu \mathrm{m}$. $C$, Changes in $\left[\mathrm{Ca}^{2+}\right]_{\mathrm{i}}(\Delta F / F)$ in cells $1-4$ during drug application. $D$, At E6, most cells respond to carbachol, and smaller numbers respond to UTP, GABA, and glutamate. Responses to UTP $(100 \mu \mathrm{M})$ and carbachol $(100 \mu \mathrm{M})$ arose equally from the mitotic and the interphase populations, whereas those to GABA $(100 \mu \mathrm{M})$ and glutamate $(100 \mu \mathrm{M})$ were predominantly from the interphase cells. Values plotted are mean $\pm \mathrm{SEM} ; N=4$.

the large mitotic and the smaller interphase cells (Fig. 5D); carbachol evoked responses in $93 \pm 4 \%$ of the mitotic and $95 \pm$ $4 \%$ of the interphase populations, whereas for UTP, the figures were $9 \pm 6$ and $13 \pm 4 \%$, respectively. In contrast, most cells responding to GABA and glutamate were members of the interphase population of small cells (Fig. $5 D$ ). For GABA, $2 \pm 0.5 \%$ of mitotic and $33 \pm 8 \%$ of interphase cells responded, whereas for glutamate, the figures were $9 \pm 3$ and $30 \pm 10.5 \%$, respectively. That the blockade of $\mathrm{GABA}_{\mathrm{A}}$ receptors affected only interphase cells (see above) suggested that these receptors may be expressed mainly by differentiating neurons. Support for this hypothesis comes from the identification, in one retina stained with TuJ-1 after $\mathrm{Ca}^{2+}$ imaging, of the cells that produced $\left[\mathrm{Ca}^{2+}\right]_{\mathrm{i}}$ transients in response to application of GABA (Fig. 6). In this experiment, of the cells that responded, $76 \%(n=45)$ were TuJ-1-positive, and none was in mitosis $(n=20)$. It remains possible that some cells possess $\mathrm{GABA}_{\mathrm{A}}$ receptors but do not express VOCCs. However, this seems unlikely, because high-K ${ }^{+}$(20 mm) Krebs' solution raised $\left[\mathrm{Ca}^{2+}\right]_{\mathrm{i}}$ in virtually all cell in all retinas challenged (data not shown).

\section{Developmental change in sensitivity to purinergic stimulation}

To investigate whether the pattern of agonist sensitivity varied during development, we compared the response to carbachol, UTP, GABA, and glutamate at E4 with that described above for E6 (Fig. 7). The size of the population of VZ cells that respond to carbachol at E4 was similar to that at E6, with $94 \pm 2 \%(n=$ $671)$ and $99 \pm 0.4 \%(n=330)$ of cells responding, respectively. However, unlike at E6, when only $11 \pm 5 \%$ of VZ cells responded to UTP, at E4, $82 \pm 8 \%(n=405)$ of cells responded. Furthermore, a large number of cells $(93 \pm 5 \% ; n=365)$ responded to both UTP and carbachol at E4. The responses to both agonists were oscillatory at both E4 and E6. Relatively few cells responded to either GABA $(8 \pm 3 \% ; n=385)$ or glutamate $(4 \pm 2 \% ; n=$ 385) at E4. 

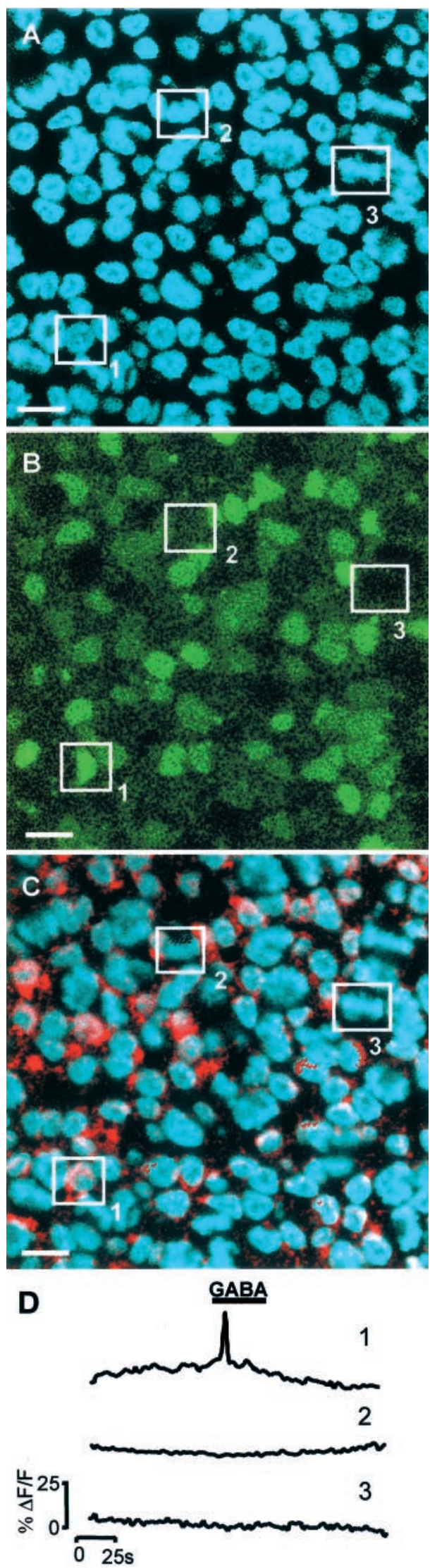

Figure 6. The responses to GABA arise primarily from newly differentiated neurons. $A-C$, Single confocal sections through the $\mathrm{VZ}$ of the same region within an E6 chick retina. $A$, Hoechst 33342 staining to show the
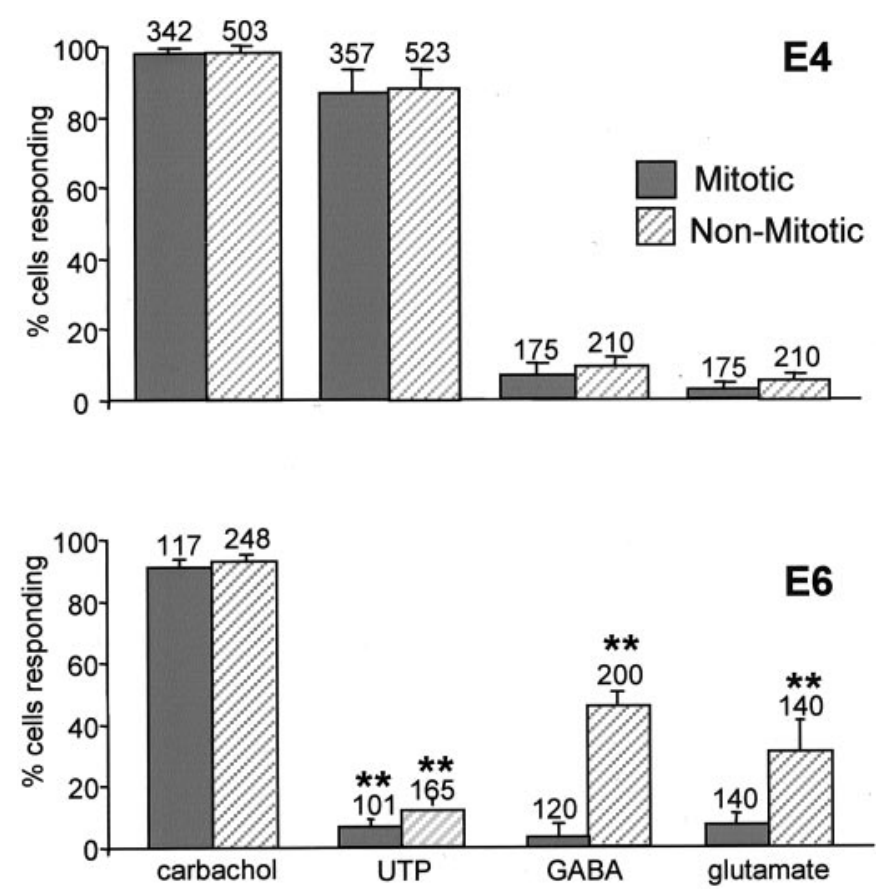

Figure 7. Developmental changes in sensitivity to neurotransmitter stimulation. $A$, Proportion of mitotic and interphase cells in the $\mathrm{VZ}$ responding to carbachol, UTP, GABA, and glutamate (all $100 \mu \mathrm{M}$ ) in E4 chick retina. $B$, Response to the same agonists at E6. Values are mean \pm SEM carbachol, $N=12$; UTP, $N=12$; GABA, $N=8$; glutamate, $N=6$ for E4; $N=4$ at E6 for all agonists; ${ }^{*} p<0.05 ;{ }^{*} p<0.01$ (E4 compared with E6 in each category).

\section{Muscarinic and purinergic, but not GABAergic or glutamatergic, receptors affect mitosis and eye development}

Many of the experiments implicating neurotransmitters in the control of cell proliferation have been performed in vitro and do not distinguish direct effects on mitosis from those that affect the cell cycle indirectly through, for example, actions on interkinetic nuclear migration, which may affect the time it takes for cells to reach the VZ, where they divide. For this reason, we used Hoechst 33342 labeling of chromatin to directly image the effects of purinergic, muscarinic, glutamatergic, and GABAergic stimulation and blockade on cell division in the VZ.

While imaging E5 retinas at $37^{\circ} \mathrm{C}$, we timed the period from entry into metaphase to chromosome separation (Fig. 8). This time was significantly reduced from $38 \pm 5$ min in controls to $12 \pm$ $2 \mathrm{~min}$ in the presence of UTP $(N=6 ; n=99 ; p<0.01 ; 10 \mu \mathrm{M})$ and slowed by suramin $(29 \pm 1 \mathrm{~min}$ in controls and $36 \pm 1 \mathrm{~min}$ in suramin; $N=4 ; n=150)$, although this effect was not significant $(p=0.17)$. Carbachol $(10 \mu \mathrm{M})$ significantly extended this interval from $33 \pm 5 \mathrm{~min}$ in controls to $62 \pm 6 \min (N=4 ; n=117 ; p<$ $0.01)$, whereas pirenzipine reduced it $(11 \pm 0.3 \mathrm{~min} ; N=3 ; n=$

\section{$\leftarrow$}

mitotic status of cells (cell indicated by box 1 is in interphase; those in boxes 2 and 3 are mitotic). B, Fluo-4 image taken during the application of GABA $(100 \mu \mathrm{M})$. C, Identification of differentiating neurons using TuJ-1 conjugated with Cy5 (red) and Hoechst 33342 (blue). The same three cells are highlighted throughout. Scale bar, $5 \mu \mathrm{m}$. $D$, Change in $\left[\mathrm{Ca}^{2+}\right]_{\mathrm{i}}(\Delta F / F)$ in cells $1-3$ in response to GABA. Cell 1 is in interphase, is TuJ-1 positive, and responds to GABA; cell 2 is in interphase, is TuJ-1 negative, and does not respond to GABA; and cell 3 is mitotic, is TuJ-1 negative, and does not respond to GABA. 


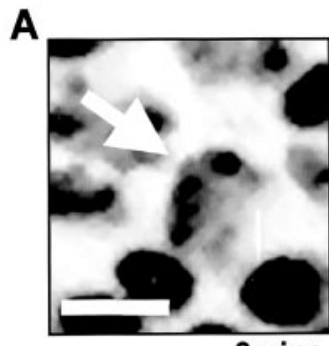

Omins

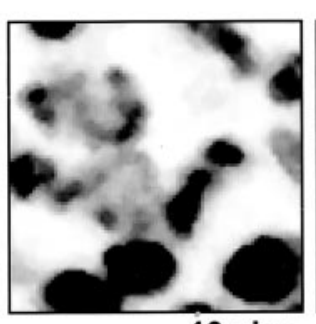

$10 \mathrm{mins}$

B

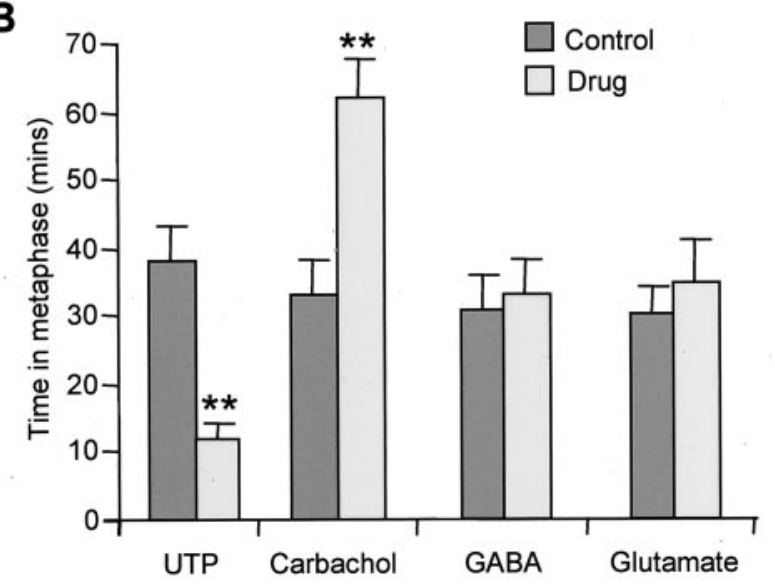

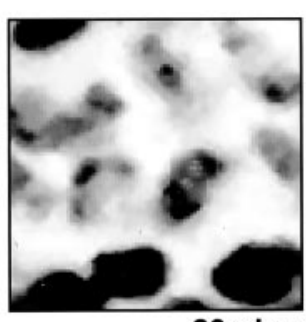

20mins

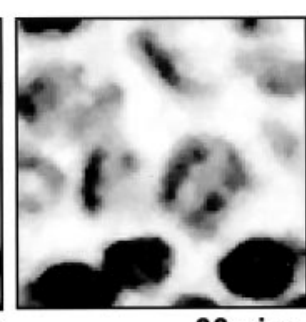

$30 \mathrm{mins}$

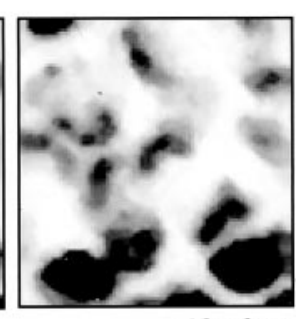

40mins

\section{C}
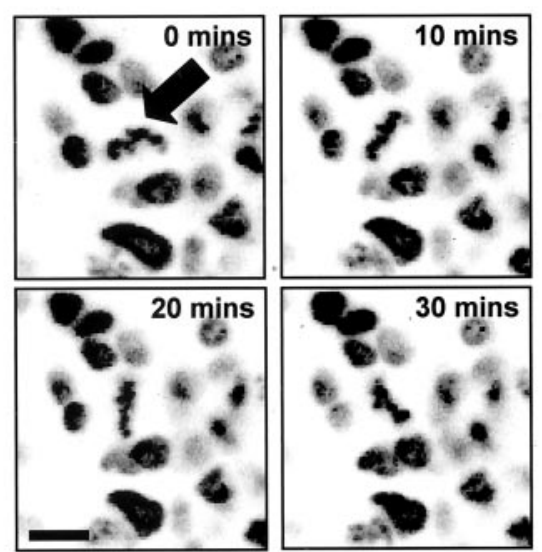

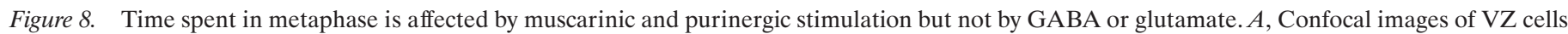

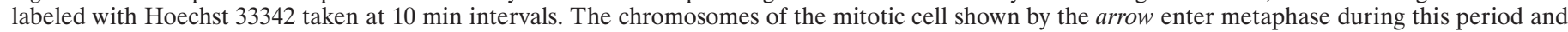

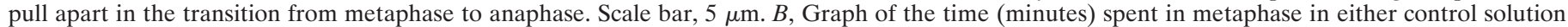

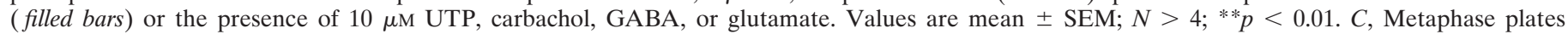
(arrowhead) also underwent rotations without separation during the period of observation (illustrated are 30 min).

$150 ; p<0.01)$. By contrast, neither glutamate nor GABA (both 10 $\mu \mathrm{M})$ had any significant effect $(N=5 ; n=105 ; p=0.55$; and $N=$ $5 ; n=82 ; p=0.86$, respectively $)$. The application of UTP $(10 \mu \mathrm{M})$ at E7, a time at which very few cells produce $\left[\mathrm{Ca}^{2+}\right]_{\mathrm{i}}$ transients in response to its application, was without effect on the time spent in metaphase ( $28 \pm 2$ min compared with $25 \pm 2$ min in controls; $N=3 ; n=150)$.

To determine whether $\left[\mathrm{Ca}^{2+}\right]_{i}$ can exert an influence on the progression of $\mathrm{VZ}$ cells through mitosis, we examined the effects of caffeine $(10 \mathrm{~mm})$ and the $\mathrm{Ca}^{2+}$ chelator BAPTA AM (100 $\mu \mathrm{M})$. Incubating retinas in BAPTA AM $(1 \mathrm{hr})$ or the presence of caffeine in the bathing solution greatly reduced the number of cells $(0.4 \pm 0.1$ vs $23 \pm 4 \%$ in controls, $N=3, n=350, p<0.01$; and $3 \pm 1$ vs $24 \pm 5 \%$ in controls, $N=6 ; n=300 ; p<0.01$ respectively) progressing through prophase to metaphase during the period over which we were able to image cells ( $~ 90 \mathrm{~min})$. These results imply that $\left[\mathrm{Ca}^{2+}\right]_{\mathrm{i}}$ is an important factor in the regulation of mitosis in $\mathrm{VZ}$ cells.

We considered the possibility that UTP and carbachol, although affecting the time spent in metaphase, may not have significant effects on a longer time scale. Because we could follow only part of the cell cycle, mitosis, by live imaging of chromatin, we examined the effect of muscarinic and purinergic receptors in the longer term by other means. First, we looked at whether prolonged stimulation or blockade of any of the transmitter receptors described above had any effect on eye growth. Second, we examined the effects of these manipulations on the number of mitotic figures seen in the VZ. In each experiment, embryos were allowed to develop in ovo in the presence of carbachol, pirenzip- ine, UTP, pyridoxal-phosphate-6-azophenyll-2' , $^{\prime}$-disulfonic acid 4-sodium (PPADS), GABA, bicuculline, glutamate, or NBQX (final concentrations, 25 and $50 \mu \mathrm{M}$ in the egg; see Materials and Methods).

Embryos grown in the presence of UTP had eyes $10 \pm 2 \%$ larger in diameter than controls $(N=4 ; p<0.04)$ (Fig. 9A). This result is consistent with the finding described above for the effects of UTP on mitosis, with increased mitotic rate leading to an increased cell number after $6 \mathrm{hr}$. The effects of the purinergic antagonist suramin on eye size could not be determined, because its application was usually lethal. However, the purinergic antagonist PPADS, which also reduces the responses to UTP and the rate of spontaneous $\left[\mathrm{Ca}^{2+}\right]_{\mathrm{i}}$ transients (data not shown), reduced eye size by $21 \pm 5 \%(N=4 ; p<0.01)$. In contrast to the effects seen with UTP, and congruent with its effects on mitosis, carbachol caused a reduction in eye size, with treated eyes $8 \pm 3 \%$ smaller than those in controls $(N=10 ; p<0.02)$. The muscarinic antagonist pirenzipine induced a change opposite to that of carbachol, eyes in the treated embryos having a diameter $7 \pm 2 \%$ greater than in controls $(N=10 ; p<0.04)$. The cell density in all eyes was not significantly different (Fig. $9 D$ ). These findings are consistent with the reduction in the rate of mitosis produced by muscarinic stimulation leading to a reduction in cell number.

Neither GABA nor bicuculline had any significant effect on eye diameter, GABA reducing eye size by $3 \pm 2 \%(N=6 ; p=0.33)$ and bicuculline increasing it by $3 \pm 3 \%(N=6 ; p=0.40)$. Applications of glutamate and NBQX were similarly without significant effect, glutamate reducing eye size by $3 \pm 3 \%(N=6$; $p=0.45)$ and NBQX reducing it by $2 \pm 2 \%(N=6 ; p=0.53)$. 

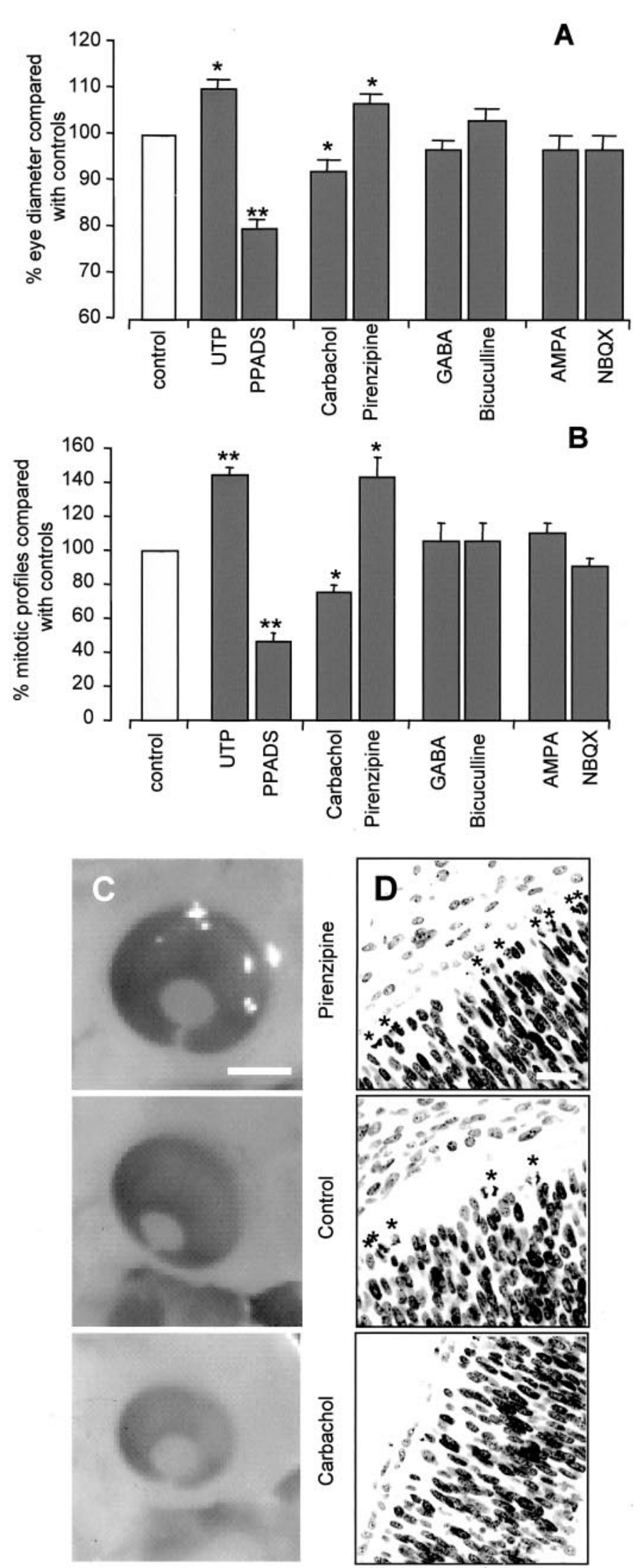

Figure 9. Eye size and mitosis are affected by muscarinic and purinergic systems but not by GABA and glutamate in ovo. $A$, Effects of UTP $(N=$ $4)$, PPADS $(N=4)$, carbachol $(N=6)$, pirenzipine $(N=10)$, GABA $(N=5)$, bicuculline $(N=5)$, glutamate $(N=5)$, and $\operatorname{NBQX}(N=5)$
After fixation, the eyes from the embryos above were sectioned and stained with Hoechst $(2 \mu \mathrm{M})$. Those sections passing through both the lens and optic disk were analyzed using a pseudorandom sampling technique (see Materials and Methods), and the number of mitotic profiles $/ 100 \mu \mathrm{m}$ length of the retina was determined (Fig. 9B). Embryos exposed to UTP showed a $45 \pm 4 \%(N=4$; $p<0.01)$ increase in the number of mitotic cells in the VZ, whereas in embryos treated with PPADS, the number was decreased by $54 \pm 5 \%(N=4 ; p=0.01)$ compared with controls. By contrast, carbachol reduced the number of mitotic profiles by $21 \pm 4 \%(N=14 ; p<0.03)$, whereas pirenzipine increased the number by $44 \pm 11 \%(N=10 ; p<0.02)$. Neither GABA $(N=$ $7 ; p=0.68)$ nor bicuculline $(N=7 ; p=0.65)$ had any significant effect on the number of mitotic profiles in the VZ, both drugs increasing mitotic cells by $6 \pm 11 \%$ compared with controls. Similarly, no effect on the number of mitotic profiles was detected with either glutamate (increase of $11 \pm 5 \%$ ) or NBQX (decrease by the same amount; $N=5 ; p=0.33$; and $N=7 ; p=0.41$, respectively). None of the drugs applied in ovo, except suramin, which was lethal, had any effect on cell death. The number of pyknotic nuclei revealed by Hoechst staining was small and did not differ significantly from that in controls (minimum $p=0.31$ ). These results are consistent with the effects of these drugs on both the changes in eye diameter and the rate of mitosis seen in the living retina and strongly suggest a role for muscarinic and purinergic receptors, but not glutamate or GABA receptors, in the regulation of cell number in the developing retina.

\section{DISCUSSION \\ Endogenous release of neurotransmitter drives spontaneous $\mathrm{Ca}^{2+}$ activity in retinal $\mathrm{VZ}$ cells}

This study demonstrates the presence of spontaneous $\left[\mathrm{Ca}^{2+}\right]_{\mathrm{i}}$ activity in chick retinal VZ cells. We show, because it is unaffected by TTX, that this activity is independent of action potential production, as it is in the cortex (Owens and Kriegstein, 1998; Owens et al., 2000). However, in contrast to the cortex, $\mathrm{Ca}^{2+}$ activity in the retinal $\mathrm{VZ}$ depends on transmitter release. By comparing the changes we see in $\left[\mathrm{Ca}^{2+}\right]_{\mathrm{i}}$ with the pattern of chromatin in cells in the VZ, we show that GABAergic and glutamatergic receptors are present within a primarily interphase population of cells. By combining $\mathrm{Ca}^{2+}$ imaging, staining of chromatin with Hoechst 33342, and immunocytochemistry for neuronal tubulin (TuJ-1), we show that GABA receptors are mainly expressed by a population of differentiating neurons. In contrast, muscarinic receptors are almost ubiquitous at E6, suggesting that these receptors play important roles in both differentiating and progenitor cells at this time. We show, using $\mathrm{Ni}^{2+}$ ions and caffeine, that the rise in $\left[\mathrm{Ca}^{2+}\right]_{\mathrm{i}}$ in response to GABA and glutamate results from a $\mathrm{Ca}^{2+}$ influx via VOCCs, whereas that in response to muscarinic and purinergic stimulation is suppressed by caffeine, frequently oscillatory in nature, and there-

\section{$\leftarrow$}

(antagonists, $25 \mu \mathrm{M}$; agonists, $50 \mu \mathrm{M}$ ), applied in ovo, on eye diameter, percent compared with controls. $B$, Effects of the same drugs on the number of mitotic figures in the VZ, percent compared with controls. Values are mean $\pm \mathrm{SEM}$; ${ }^{*} p<0.05 ;{ }^{*} p<0.01$. $C$, $D$, Examples of embryos treated with pirenzipine (top), control (center), and carbachol (bottom). C, Light microscopic images of whole eyes. Scale bar, $2 \mathrm{~mm} . D$, Confocal images of retinal sections labeled with Hoechst 33342. *Mitotic cells. Cell density is unaffected (cells/5000 $\mu \mathrm{m}^{2}$ : controls, 94-103; all drugs, 95-102; $p=0.37-0.99)$. Scale bar, $10 \mu \mathrm{m}$. 
fore likely to result from the release of $\mathrm{Ca}^{2+}$ from intracellular stores rather than $\mathrm{Ca}^{2+}$ influx.

We show that the expression of transmitter receptors by progenitor cells changes with time; whereas most mitotic and interphase cells respond only to carbachol, and not UTP, at E6, most cells respond to both agonists at E4. The functional significance of this change in the pattern of receptor expression with time is unknown, but it is possible that it correlates with a switch from symmetrical division of progenitors at early times in development, necessary for a rapid increase in the number of cells in the progenitor pool, to increased numbers of asymmetric divisions, necessary for creating large numbers of differentiated cells at later times (Desai and McConnell, 2000).

\section{Muscarinic and purinergic, but not ionotropic glutamate or GABA, receptors regulate the cell cycle}

We demonstrate, by directly imaging part of the mitotic process, that both muscarinic and purinergic stimulation may significantly affect the rate of mitosis in the retina. Muscarinic stimulation acts as a brake on mitosis at metaphase, almost doubling the time it takes for chromosomes to separate, whereas purinergic stimulation acts as an accelerator, reducing the time taken for this process to one-third. These effects of muscarinic and purinergic stimulation do not appear to be compensated for later in the cell cycle, because the presence of UTP, PPADS, carbachol, and pirenzipine for a longer period have marked effects on eye size consistent with the short-term effects of these agents on mitosis. The $\mathrm{Ca}^{2+}$ signals generated by exogenous muscarinic and purinergic stimulation are similar in magnitude, and both are oscillatory, with a frequency that depends on the concentration of the agonist. The different effects of the two receptors on the rate of mitosis may be attributable to one or more of several factors. For example, the association of the production of other second messengers in addition to $\mathrm{Ca}^{2+}$ or the coupling of the receptors to $\mathrm{Ca}^{2+}$ stores in different locations within the same cells (Short et al., 2000). It is also possible that the acetylcholine and ATP released endogenously produce signals of a different magnitude or frequency that code for their different effects (Dolmetsch et al., 1997).

$\left[\mathrm{Ca}^{2+}\right]_{\mathrm{i}}$ transients are associated with progression through checkpoints in the cell cycle (Ciapa et al., 1994) (for review, see Santella, 1998; Santella et al., 1998) and are correlated with events such as pronuclear migration, nuclear envelope breakdown, the metaphase-anaphase transition of mitosis, and cytokinesis. Owens and Kriegstein (1998) put forward the hypothesis that $\mathrm{Ca}^{2+}$ activity can influence the cell cycle in the embryonic CNS. Here we show that progress from metaphase to anaphase is strongly affected by purinergic and muscarinic receptors, which generate conspicuous $\mathrm{Ca}^{2+}$ activity in VZ cells. It is tempting to speculate that the transmitter-evoked release of $\mathrm{Ca}^{2+}$ from stores within progenitor cells exerts a direct effect on the rate of mitosis. $\left[\mathrm{Ca}^{2+}\right]_{\mathrm{i}}$ signals have been shown previously to be important in controlling the cell cycle (for review, see Whitaker and Larman, 2001). If this is so, it would provide a mechanism by which molecules such as neurotransmitters could regulate cell division and exert control over both cell number and the timing of the production of the different types of CNS cells. Although we did not attempt to examine the affects of agonist-induced $\left[\mathrm{Ca}^{2+}\right]_{\mathrm{i}}$ transients on metaphase rotation, a process that may be important in determining the cleavage plane, this presents a potential a mechanism by which progenitor cell divisions could be biased toward symmetrical division and the production of further progenitors rather than differentiated cells.

Despite the frequency of spontaneous $\left[\mathrm{Ca}^{2+}\right]_{\mathrm{i}}$ transients among VZ cells being low $(\sim 0.004 \mathrm{~Hz})$, on average, eight such transients would occur during the period between metaphase and chromosome separation alone, and if the frequency of these events is similar throughout the cell cycle $(\sim 10 \mathrm{hr}$; Morris and Cowan, 1995), then progenitor cells would be subject to up to 150 events between divisions. Such a barrage could exert a powerful influence on a wide variety of cell cycle events. In a more intact preparation, including the RPE, the frequency of spontaneous $\left[\mathrm{Ca}^{2+}\right]_{\mathrm{i}}$ transients is higher than in the isolated retina (our unpublished observations). The increased frequency may result from the release of ATP from the RPE, shown to occur in human cell lines (Mitchell, 2001).

LoTurco et al. (1995) showed that, in embryonic neocortex, GABA and glutamate decrease the number of dissociated embryonic cortical cells synthesizing DNA and that $\mathrm{GABA}_{\mathrm{A}}$ and AMPA/kainate receptor antagonists increase DNA synthesis, indicating that endogenously released amino acids influence neocortical progenitors in the cell cycle. They suggest that GABA and glutamate bring about their actions through depolarizationevoked $\left[\mathrm{Ca}^{2+}\right]_{\mathrm{i}}$ increases. The findings we report here show that, in the chick retina, the actions of GABA and glutamate also produce increases in $\left[\mathrm{Ca}^{2+}\right]_{\mathrm{i}}$, but that, in contrast to the findings of LoTurco et al. (1995), the $\mathrm{Ca}^{2+}$ influx through VOCCs that they evoke does not appear to regulate mitosis. An interesting possibility is that in the neocortex, the actions of GABA and glutamate may be to depolarize differentiated neurons and to bring about the release of some factor, which then acts to regulate the cell cycle. However, this does not appear to be the case in the retina, because both glutamatergic and GABAergic stimulation and blockade were without effect on mitosis or eye development. Nevertheless, because transmitter systems interact to regulate early electrical activity (Wong et al., 2000), at times before both neurogenesis is complete and synapse formation has occurred (Catsicas et al., 1998), this possibility is worthy of further investigation. In addition to their potential role in the regulation of the cell cycle, both glutamate and GABA receptors have been shown to regulate the migration of differentiated cells in the brain (Rossi and Slater, 1993; Rakic and Komuro, 1995; Komuro and Rakic, 1996). If these receptors are involved in such a role in the retina, their presence in newly differentiated cells in the VZ is not surprising.

Because the VZ is the only place within the developing retina where progenitor cells divide, it is possible that muscarinic and purinergic receptors may play a further role in the control of the cell cycle through regulating the rate at which cells undergo interkinetic nuclear migration and reach the VZ. Alternatively, it is possible, because such transients have been shown to occur during other phases of the cell cycle (Santella, 1998), that muscarinic and purinergic stimulation of $\left[\mathrm{Ca}^{2+}\right]_{i}$ transients during the $\mathrm{G}-\mathrm{S}$ transition and during $\mathrm{S}$ phase, which occur outside the $\mathrm{VZ}$, regulate the rate of proliferation. To determine whether this is so, it will be necessary to image cells as their nuclei move through the retina during interkinetic nuclear migration.

\section{REFERENCES}

Antonopoulos J, Pappas IS, Parnavelas JG (1997) Activation of the $\mathrm{GABA}_{\mathrm{A}}$ receptor inhibits the proliferative effects of bFGF in cortical progenitor cells. Eur J Neurosci 9:291-298.

Baumgold J, Dyer K (1994) Muscarinic receptor-mediated inhibition of 
mitogenesis via a protein kinase $\mathrm{C}$-independent mechanism in M1transfected A9L cells. Cell Signal 6:103-108.

Catsicas M, Mobbs P (2001) GABAb receptors regulate chick retinal calcium waves. J Neurosci 21:897-910.

Catsicas M, Bonness V, Becker D, Mobbs P (1998) Spontaneous Ca ${ }^{2+}$ transients and their transmission in the developing chick retina. Curr Biol 8:283-286.

Ciapa B, Pesando D, Wilding M, Whitaker M (1994) Cell-cycle calcium transients driven by cyclic changes in inositol trisphosphate levels. Nature 368:875-878. 0

Ciccarelli R, Di Iorio P, Ballerini P, Ambrosini G, Giuliani P, Tiboni GM, Caciagli F (1994) Effects of exogenous ATP and related analogues on the proliferation rate of dissociated primary cultures of rat astrocytes. J Neurosci Res 39:556-566.0

Desai AR, McConnell SK (2000) Progressive restriction in fate potential by neural progenitors during cerebral cortical development. Development 127:2863-2872.

Dolmetsch RE, Lewis RS, Goodnow CC, Healy JI (1997) Differential activation of transcription factors induced by calcium response amplitude and duration. Nature 386:855-858.

Fiszman ML, Broodinsky LN, Neale JH (1999) GABA induces proliferation of immature cerebellar granule cells grown in vitro. Brain Res Dev Brain Res 115:1-8.

Haydar TF, Wang F, Schwartz ML, Rakic P (2000) Differential modulation of proliferation in the neocortical ventricular and subventricular zones. J Neurosci 20:5764-5774.

Jacobson M (1978) Developmental neurobiology. New York: Plenum.

Komuro H, Rakic P (1996) Intracellular Ca ${ }^{2+}$ fluctuations modulate the rate of neuronal migration. Neuron 17:275-285.

Lee MK, Tuttle JB, Rebhun LI, Cleveland DW, Frankfurter A (1990) The expression and posttranslational modification of a neuron-specific beta-tubulin isotope during chick embryogenesis. Cell Motil Cytoskeleton 17:118-132.

Li BS, Ma W, Zhang L, Barker JL, Stenger DA, Pant HC (2001) Activation of phosphatidylinositol-3 kinase (PI-3K) and extracellular regulated kinases (Erk1/2) is involved in muscarinic receptor-mediated DNA synthesis in neural progenitor cells. J Neurosci 21:1569-1579.

LoTurco JJ, Owens DF, Heath MJ, Davis MB, Kriegstein AR (1995) GABA and glutamate depolarize cortical progenitor cells and inhibit DNA synthesis. Neuron 15:1287-1298.

Ma W, Maric D, Li BS, Hu Q, Andreadis JD, Grant GM, Liu QY, Shaffer KM, Chang YH, Zhang L, Pancrazio JJ, Pant HC, Stenger DA, Barker JL (2000) Acetylcholine stimulates cortical precursor cell proliferation in vitro via muscarinic receptor activation and MAP kinase phosphorylation. Eur J Neurosci 12:1227-1240.

McCabe KL, Gunther EC, Reh TA (1999) The development of the pattern of retinal ganglion cells in the chick retina: mechanisms that control differentiation. Development 126:5713-5724.

Mitchell CH (2001) Release of ATP by a human retinal pigment epithelial cell line: potential for autocrine stimulation through subretinal space. J Physiol (Lond) 534:193-202.

Morris VB, Cowan R (1995) An analysis of the growth of the retinal cell population in embryonic chicks yielding proliferative ratios, numbers of proliferative and non-proliferative cells and cell-cycle times for successive generations of cell cycles. Cell Prolif 28:373-391.

Nicke B, Dtejen K, Logsdon CD (1999) Muscarinic cholinergic recep- tors activate both inhibitory and stimulatory growth mechanisms in NIH3T3 cells. J Biol Chem 274:21701-21706.

Owens DF, Kriegstein AR (1998) Patterns of intracellular calcium fluctuation in precursor cells of the neocortical ventricular zone. J Neurosci 18:5374-5388.

Owens DF, Flint AC, Dammerman RS, Kriegstein AR (2000) Calcium dynamics of neocortical ventricular zone cells. Dev Neurosci 22:25-33.

Perron M, Harris WA (2000) Determination of vertebrate retinal progenitor cell fate by the Notch pathway and basic helix-loop-helix transcription factors. Cell Mol Life Sci 57:215-223.

Prada C, Puga J, Perez-Mendez L, Lopez R, Ramirez G (1991) Spatial and temporal patterns of neurogenesis in the chick retina. Eur J Neurosci 3:559-569.

Rakic P, Komuro H (1995) The role of receptor/channel activity in neuronal cell migration. J Neurobiol 26:299-315.

Rossi DJ, Slater NT (1993) The developmental onset of NMDA receptor-channel activity during neuronal migration. Neuropharmacology 32:1239-1248.

Sakaki Y, Fukuda Y, Yamashita M (1996) Muscarinic and purinergic $\mathrm{Ca}^{2+}$ mobilizations in the neural retina of early embryonic chick. Int $\mathrm{J}$ Dev Neurosci 14:691-699.

Santella L (1998) The role of calcium in the cell cycle: facts and hypotheses. Biochem Biophys Res Commun 244:317-324.

Santella L, Kyozuka K, De Riso L, Carafoli E (1998) Calcium, protease action, and the regulation of the cell cycle. Cell Calcium 23:123-130.

Schwahn HN, Kaymak H, Schaeffel F (2000) Effects of atropine on refractive development, dopamine release, and slow retinal potentials in the chick. Vis Neurosci 17:165-176.

Short AD, Winston GP, Taylor CW (2000) Different receptors use inositol trisphosphate to mobilize $\mathrm{Ca}(2+)$ from different intracellular pools. Biochem J 351:683-686.

Sugioka M, Fukuda Y, Yamashita M (1996) $\mathrm{Ca}^{2+}$ responses to ATP via purinoceptors in the early embryonic chick retina. J Physiol (Lond) 493:855-863.

Sugioka M, Fukuda Y, Yamashita M (1998) Development of glutamateinduced intracellular $\mathrm{Ca}^{2+}$ rise in the embryonic chick retina. J Neurobiol 34:113-125.

Sugioka M, Zhou WL, Hofmann HD, Yamashita M (1999a) Involvement of P2 purinoceptors in the regulation of DNA synthesis in the neural retina of chick embryo. Int J Dev Neurosci 17:135-144.

Sugioka M, Z hou WL, Hofmann HD, Yamashita M (1999b) Ca ${ }^{2+}$ mobilization and capacitative $\mathrm{Ca}^{2+}$ entry regulate DNA synthesis in cultured chick retinal neuroepithelial cells. Int $\mathrm{J}$ Dev Neurosci 17:163-172.

Tigges M, Iuvone PM, Fernandes A, Sugrue MF, Mallorga PJ, Laties AM, Stone RA (1999) Effects of muscarinic cholinergic receptor antagonists on postnatal eye growth of rhesus monkeys. Optom Vis Sci 76:397-407.

Whitaker M, Larman MG (2001) Calcium and mitosis. Semin Cell Dev Biol 12:53-58.

Wong WT, Myhr KL, Miller ED, Wong RO (2000) Developmental changes in the neurotransmitter regulation of correlated spontaneous retinal activity. J Neurosci 20:351-360.

Yamashita M, Fukuda Y (1993) Calcium channels and GABA receptors in the early embryonic chick retina. J Neurobiol 24:1600-1614. 